\title{
KRADZIEŻ CZY PRZYWEASZCZENIE RZECZY RUCHOMEJ Z MAJĄTKU WSPÓLNEGO (WSPÓŁWŁASNOŚCI)?
}

Od wielu lat w polskiej doktrynie sporny charakter ma kwalifikacja zachowania polegającego na przywłaszczeniu (kradzieży) rzeczy ze współwłasności. Na wstępie należy podkreślić, że prawo cywilne wyróżnia dwa rodzaje współwłasności. Zgodnie z art. $196 \S 1$ k.c. współwłasność jest albo współwłasnością w częściach ułamkowych, albo współwłasnością łączną. Współwłasność łączną regulują przepisy dotyczące stosunków, z których ona wynika (art. 196 $\S 2$ k.c.). W doktrynie prawa cywilnego podkreśla się, że współwłasność w częściach ułamkowych jest „,samoistnym stosunkiem prawnym prawa rzeczowego niezwiązanym ze stosunkiem prawnym innego rodzaju. Częstokroć jest stosunkiem przypadkowym. Z założenia zaś jest stosunkiem nietrwałym. Natomiast współwłasność łączna wiąże się zawsze z innym, podstawowym, osobistym stosunkiem prawnym i spełnia względem niego rolę służebną. Istnieje dla wzmocnienia nadrzędnego stosunku osobistego, by spełniał on nale-

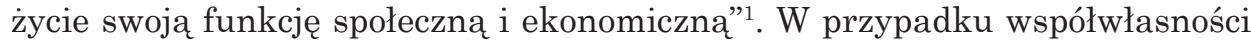
w częściach ułamkowych współwłaścicielowi przysługuje określony ułamkowo udział we współwłasności. Natomiast we współwłasności łącznej brak określenia wartości udziału, gdyż podważałoby to nadrzędny stosunek osobisty, który łączy współwłaścicieli. Udziały takie powstają dopiero w chwili zniesienia współwłasności łącznej. Staje się wtedy ona współwłasnością w częściach ułamkowych. Druga różnica dotyczy możliwości rozporządzenia udziałem. Współwłasność w częściach ułamkowych uprawnia współwłaściciela do swobodnego rozporządzenia swoim udziałem w każdym czasie (art. 198 k.c.).

Natomiast w przypadku współwłasności łącznej zasadniczo nie można rozporządzać swoim udziałem. Nie może być ona także zniesiona w czasie trwania podstawowego stosunku prawnego o charakterze osobistym, który łaczy współwłaścicieli (w przeciwieństwie do współwłasności w częściach ułamkowych). Jego ustanie powoduje przekształcenie współwłasności łącznej we współwłasność w częściach ułamkowych i wtedy dopiero możliwe jest zniesienie współwłasności, czyli podział majątku. Ma więc ona charakter bezudziałowy aż do czasu ustania podstawowego stosunku prawnego.

Współwłasność łączna występuje w stosunkach majątkowych pomiędzy małżonkami oraz wspólnikami spółki cywilnej. Natomiast przykładem współwłasności w częściach ułamkowych jest współwłasność rzeczy. Zgodnie z art. $31 \S$ k.r.o.: „z chwilą zawarcia małżeństwa powstaje między małżonka-

${ }^{1}$ E. Gniewek, Prawo rzeczowe, Warszawa 2006, s. 132. 
mi z mocy ustawy wspólność majątkowa (wspólność ustawowa) obejmująca przedmioty majątkowe nabyte w czasie jej trwania przez oboje małżonków lub przez jednego z nich (majątek wspólny). Przedmioty majątkowe nieobjęte wspólnością ustawową należą do majątku osobistego każdego z małżonków”. Przepis art. 35 k.r.o. stanowi, że: „w czasie trwania wspólności ustawowej żaden z małżonków nie może żądać podziału majątku wspólnego. Nie może również rozporządzać ani zobowiązywać się do rozporządzania udziałem, który w razie ustania wspólności przypadnie mu w majątku wspólnym lub w poszczególnych przedmiotach należących do tego majątku”.

W doktrynie podkreśla się, że mienie wchodzące w skład współwłasności małżonków nie jest w pełni mieniem własnym każdego z nich. Dla każdego z małżonków jest ono częściowo mieniem cudzym². Moim zdaniem wykładnia terminu „cudza” nie może nastapić na podstawie znaczenia, jakie temu terminowi przypisuje się w języku powszechnym. Jest to więc pojęcie technicznoprawne i należy przyjąć jego rozumienie w języku prawnym i prawniczym ${ }^{3}$. Powszechnie przyjmuje się w literaturze, że rzecz stanowiąca przedmiot współwłasności jest rzeczą cudzą w rozumieniu prawa karnego dla każdego ze współwłaścicieli ${ }^{4}$. Mieniem „cudzym” jest takie, którym sprawca nie ma prawa wyłącznie rozporządzać. Termin „cudze” oznacza, że ma ono właściciela i że do tego mienia nie przysługuje sprawcy przestępstwa żadne prawo rzeczowe wyłączające inne osoby.

Leszek Kubicki podkreśla, że: „»jednostronne« uszczuplenie mienia objętego małżeńską wspólnością w postaci zaboru czy przywłaszczenia jest przedmiotowo zamachem na "mienie cudze«, gdyż dopóki mienie jest wspólne, nie może być jednocześnie własnym jednego z małżonków. Wszelkie konstrukcje podwójnej własności na tle obowiązującego ustawodawstwa są niedopuszczalne. Okoliczność więc, że przywłaszczony przez sprawcę przedmiot majątkowy, stanowiący w chwili czynu współwłasność, może kiedyś w przyszłości stać się jego własnościa, dla bytu kradzieży czy przywłaszczenia nie ma znaczenia, gdyż sprawca przywłaszczył mienie, które w chwili czynu nie stanowiło

2 R.A. Stefański, Odpowiedzialność karna za zabór mienia stanowiąego wspólnośc majątkowa, „Prokuratura i Prawo” 1995, nr 10, s. 118. Tak też wyrok SN z 24 lutego 1937 r., 2 K 1661/36, „Zbiór Orzeczeń SN” 1937, nr 9, poz. 255.

3 Trafne jest stwierdzenie A. Piaczyńskiej (Przywłaszczenie składnika spadku przez wspótspadkobierce, „Prokuratura i Prawo” 2011, nr 3, s. 91-92), że uznanie rzeczy stanowiącej współwłasność za cudzą dla współwłaścicieli następuje na drodze wykładni celowościowej.

${ }^{4}$ O. Górniok, w: eadem, S. Hoc, S. Przyjemski, Kodeks karny. Komentarz, t. 3, Gdańsk 1999, s. 342. Orzecznictwo przyjmuje tak powszechnie już od czasów przedwojennych. Zob. wyroki SN: z 18 września 1934 r., 1 K 487/34, „Zbiór Orzeczeń SN” 1935, nr 3, poz. 102; z 19 grudnia 1934 r., 1 K 987/34, „Zbiór Orzeczeń SN” 1935, nr 7, poz. 287; z 24 lutego 1937 r., „Zbiór Orzeczeń SN” 1937, nr 9, poz. 255). Także w doktrynie nigdy nie było wątpliwości w tym zakresie. Zob. S. Glaser, A. Mogilnicki, Kodeks karny. Komentarz, Kraków 1934, s. 879-880; L. Peiper, Komentarz do Kodeksu karnego i Prawa o wykroczeniach, Kraków 1936, s. 544; J. Makarewicz, Kodeks karny z komentarzem, Lwów 1932, s. 585; M. Siewierski, Kodeks karny i Prawo o wykroczeniach. Komentarz, Warszawa 1963, s. 346; J. Wojciechowski, Mienie jako przedmiot przestępstwa kradzieży, „Annales UMCS, sectio G” 23, 1976, s. 294. W literaturze niemieckiej, szwajcarskiej, francuskiej i belgijskiej powszechnie przyjmuje się możliwość kradzieży rzeczy z majątku wspólnego przez współwłaściciela. Zob. J. Wojciechowski, op. cit., s. 294 i powołana tam literatura. 
jego własności”. Trafnie wskazuje on, że mienie wchodzące w skład majątku wspólnego małżonków nie może być „upośledzone” w zakresie ochrony prawnokarnej, ponieważ ograniczeń tych nie da się uzasadnić. Względnie wnioskowy tryb ścigania stanowi skuteczną ochronę przed niepożądaną ingerencją karną w wewnętrzne stosunki małżeńskie ${ }^{6}$.

Zdaniem Ryszarda A. Stefańskiego za takim charakterem przemawia przede wszystkim art. 35 k.r.o., który podkreśla bezudziałową współwłasność łączną. „Oceny tej nie zmienia fakt, iż każdy z małżonków jest uprawniony na mocy art. $36 \S 1$ k.r.o. - do podejmowania samodzielnie czynności prawnych i działań faktycznych w stosunku do majątku wspólnego"7. W literaturze wskazuje się, że każdy z małżonków, podejmując określone działania faktyczne lub prawne mające za przedmiot składniki majątku wspólnego, powinien liczyć się z wyraźną lub dorozumianą wolą drugiego małżonka, który powinien udzielać współmałżonkowi niezbędnej pomocy w wykonywaniu zarządu i nie utrudniać podejmowania działań celowych w stosunku do majątku wspólnego ${ }^{8}$.

W doktrynie i w orzecznictwie zdecydowanie dominuje stanowisko, że małżonek, który rozporządza składnikiem majątku wspólnego jak własnym, wbrew woli drugiego małżonka, popełnia kradzież lub przywłaszczenie, w zależności od tego, czy rzecz znajduje się we władztwie pokrzywdzonego, czy też sprawcy ${ }^{9}$. Przykładem takiego rozporządzenia jest sprzedaż rzeczy. Zdaniem Bogusława Michalskiego możliwa jest kradzież składników majątku wspólnego przez jednego ze współmałżonków ${ }^{10}$. Także R.A. Stefański podkreśla, że rzeczy wchodzące w skład majątku wspólnego małżonków mogą być w posiadaniu każdego z małżonków, gdyż każde z nich może samodzielnie wykonywać zarząd majątkiem. Jeżeli małżonek dopuści się czynu w stosunku do mienia posiadanego przez siebie, to czyn ten należy kwalifikować jako przestępstwo przywłaszczenia, a gdy przedmiotem wykonawczym będzie rzecz znajdująca się w posiadaniu drugiego małżonka - jako przestępstwo kradzieży. Relewantną okolicznością jest posiadanie rzeczy w czasie czynu ${ }^{11}$.

Leszek Wilk trafnie wskazuje, że: ,jeżeli [...] istota zaboru polega na wyjęciu rzeczy spod władztwa jej dysponenta, to może się go dopuścić tylko ten,

${ }^{5}$ L. Kubicki, W sprawie „Problematyki zaboru przez jednego z matżonków mienia objętego wspótwtasnościq ustawowa”, „Państwo i Prawo” 1959, z. 11, s. 856.

${ }^{6}$ Ibidem, s. 856.

${ }^{7}$ R.A. Stefański, op. cit., s. 118.

8 J. Ignatowicz et al., Kodeks rodzinny i opiekuńczy z komentarzem, Warszawa 1990, s. 195.

${ }^{9}$ Zob. R.A. Stefański, op. cit., s. 118 i n.; M. Kulik, w: M. Mozgawa (red.), Kodeks karny. Praktyczny komentarz, Kraków 2006, s. 538; E. Pływaczewski, E. Guzik-Makaruk, w: M. Filar (red.), Kodeks karny. Komentarz, Warszawa 2012, s. 1230; J. Bafia, w: idem, K. Mioduski, M. Siewierski, Kodeks karny. Komentarz, Warszawa 1987, s. 530; W. Świda, w: I. Andrejew, W. Świda, W. Wolter, Kodeks karny z komentarzem, Warszawa 1973, s. 611; postanowienie SN z 19 listopada 1957 r., II KO 83/57, „Ruch Prawniczy, Ekonomiczny i Socjologiczny” 20, 1958, z. 4, s. 332; wyroki SN: z 14 listopada 1972 r., V KRN 421/72, „Orzecznictwo Sąu Najwyższego Izba Karna i Wojskowa” 1973, nr 5, poz. 61; z 15 kwietnia 1985 r., II KR 37/85, „Orzecznictwo Sądu Najwyższego. Wydawnictwo Prokuratury Generalnej” 1986, nr 2, poz. 21.

${ }^{10}$ B. Michalski, w: A. Wasek (red.), Kodeks karny. Komentarz, t. 2, Warszawa 2004, s. 766. Tak też E. Pływaczewski, w: A. Marek (red.), Prawo karne, Warszawa 1997, s. 394.

${ }^{11}$ R.A. Stefański, op. cit., s. 121. 
kto w żadnym zakresie dysponentem rzeczy nie jest, tzn. w ogóle nie ma prawa rzeczą rozporządzać. Tymczasem współwłaściciel ma prawo rozporządzania rzecza, z tym tylko, iż w zależności od konkretnego układu faktycznego może to czynić albo w porozumieniu i za zgodą pozostałych współwłaścicieli, albo w ograniczonym zakresie samodzielnie. [...] Fakt, że jeden ze współwłaścicieli nie wykonywał akurat efektywnie władztwa nad rzeczą objętą współwłasnościa, nie ma tu znaczenia, jeżeli znajdował się w sytuacji umożliwiającej mu w ogóle korzystanie z tej rzeczy. Jeżeli zatem jedno ze współmałżonków zabiera rzecz objętą współwłasnościa majątkową małżeńska, by rozporządzić nią tak, jak gdyby rzecz ta stanowiła jego wyłączną własność, to dopuszcza się przywłaszczenia, a nie kradzieży"12.

Odosobnione jest stanowisko Andrzeja Stelmachowskiego ${ }^{13}$. Jego zdaniem w omawianym przypadku nie następuje zabór i należy przypisać odpowiedzialność karna za przekroczenie uprawnień w prowadzeniu cudzych spraw majątkowych. Zdaniem L. Kubickiego czynność wykonawcza jest związana nie tyle z zarządem cudzym majątkiem, ile z posiadaniem mienia wspólnego. Małżonek zaczyna je traktować jako własne, co potwierdza określoną czynnościa. Włącza on więc mienie wspólne do swojego majątku odrębnego bez ekwiwalentu dla drugiego małżonka ${ }^{14}$.

Trafnie wskazuje się w doktrynie, że „nie przekreśla elementów konstrukcyjnych wspólności ustawowej majątkowej małżeńskiej na przykład to, iż akurat jeden ze współwłaścicieli nie wykonywał efektywnie władztwa nad rzecza stanowiąca składnik wspólności majątkowej małżeńskiej, jednak znajdował się w sytuacji umożliwiającej mu w ogóle korzystanie z rzeczy"15. Dlatego też należy opowiedzieć się mniejszościowym stanowiskiem ${ }^{16}$, zgodnie z którym nie jest możliwa kradzież rzeczy wchodzacych w skład wspólnoty majątkowej małżonków, a bezprawne ich przywłaszczenie należy kwalifikować z art. 284 $\S 1$ k.k.

Odosobniony jest pogląd Małgorzaty Gałązi, zdaniem której omawiany czyn jest co prawda kwalifikowany z art. $284 \S 1$ k.k., lecz w odmianie maja-

${ }^{12}$ L. Wilk, w: M. Królikowski, R. Zawłocki (red.), Kodeks karny. Część szczególna, t. 2, Warszawa 2013, s. 532 .

${ }^{13}$ A. Stelmachowski, Jeszcze $w$ sprawie zaboru przez jednego z matżonków mienia objętego wspólnościq ustawowa, „Państwo i Prawo” 1960, z. 4-5, s. 783-785.

${ }^{14}$ L. Kubicki, Granice zarzqdu wspólnym mieniem matżonków a odpowiedzialność karna, „Państwo i Prawo” 1960, z. 4-5, s. 785 i n.

${ }_{15}$ M. Dabrowska-Kardas, P. Kardas, w: A. Zoll (red.), Kodeks karny. Komentarz. Częśc szczególna, t. 3, Kraków 2006, s. 46. Tak też J. Satko, Glosa do wyroku SN z 9 kwietnia 1997 r., III KKN 241/96, „Orzecznictwo Sądów Polskich” 1998, nr 5, poz. 95.

${ }^{16}$ Tak trafnie M. Dąbrowska-Kardas, P. Kardas, w: A. Zoll (red.), op. cit., s. 45-46; L. Wilk, w: M. Królikowski, R. Zawłocki (red.), op. cit., s. 533; M. Gałąka, w: A. Grześkowiak, K. Wiak (red.), Kodeks karny. Komentarz, Warszawa 2012, s. 1175; T. Oczkowski, A. Marek, w: R. Zawłocki (red.), System prawa karnego, t. 9: Przestęstwa przeciwko mieniu i gospodarcze, Warszawa 2011, s. 76; A. Sośnicka, Przestęstwo i wykroczenie przywłaszczenia w polskim prawie karnym, Warszawa 2013, s. 173 i n.; wyrok SN z 6 stycznia 1978 r., V KR 197/77, „Orzecznictwo Sądu Najwyższego. Wydawnictwo Prokuratury Generalnej” 1978, nr 6, poz. 64; wyrok SA w Krakowie z 14 sierpnia 2002 r., II AKa 1295/02, „Krakowskie Zeszyty Sądowe” 2002, nr 9, poz. 13. 
cej za przedmiot prawo majątkowe, a nie rzecz ruchomą ${ }^{17}$. Podkreśla ona, że uznawanie takiego czynu za kradzież lub przywłaszczenie rzeczy ruchomej opiera się na założeniu, że ta sama rzecz może być dla określonej osoby jednocześnie cudza oraz własna. Natomiast zgodnie z art. 195 k.c. rzecz wspólna jest dla współuprawnionego rzeczą własna, z tym zastrzeżeniem, że jest ona także rzeczą własną dla innej osoby (osób). Dlatego też, zdaniem powołanej autorki, następuje tu przywłaszczenie prawa majątkowego, a nie rzeczy ruchomej (art. $284 \S 1$ k.k.). Stanowisko to zasługuje na uwagę. Nie wymaga ono bowiem odstępowania od cywilistycznego rozumienia terminu „rzecz cudza” i tworzenia technicznoprawnego znaczenia tego pojęcia jedynie na użytek prawa karnego.

Sąd Najwyższy podkreślił, że przywłaszczenie składnika majątku wspólnego jako realizacja zamiaru powiększenie swojego majątku kosztem małżonka może polegać także na „wyjęciu” rzeczy z majątku wspólnego po to, aby nie stał się on w przyszłości przedmiotem podziału majątku wspólnego z pokrzywdzeniem małżonka i z jednoczesną korzyścią dla osoby, która samowolnie rzecz sprzedała ${ }^{18}$.

Wydaje się, że ustalenie, czy w stosunku do majątku stanowiącego współwłasność współwłaściciel popełnia kradzież czy przywłaszczenie, zależy od ustalenia karnoprawnego rozumienia posiadania (władania). Powszechnie przyjmuje się, że chodzi o faktyczne władanie rzeczą. Przy takim założeniu nie jest istotny przepis art. $34^{1}$ k.r.o., gdyż stanowi on tylko o uprawnieniu do współposiadania rzeczy wchodzących w skład majątku wspólnego. Natomiast faktycznie uprawnienie może nie być wykonywane. Brak efektywnego wykonywania władztwa nad rzecza jest bez znaczenia dla kwalifikacji (kradzież czy przywłaszczenie), jeżeli współmałżonek znajdował się w sytuacji umożliwiającej mu w ogóle korzystanie z tej rzeczy. Małżonek włada więc np. samochodem znajdującym się we wspólnocie majątkowej nawet wtedy, gdy wcale nim nie jeździ. Jego sprzedaż wbrew jego woli przez współmałżonka może być co najwyżej zakwalifikowana jako przestępstwo przywłaszczenia (po wypełnieniu jego znamion), a nie kradzieży. Władztwo w rozumieniu prawa karnego nie oznacza wymogu codziennego czy nawet sporadycznego korzystania z rzeczy. Właściciel włada rzecza, gdyż jest jej właścicielem (współwłaścicielem) i nie traci statusu władającego nią nawet wtedy, gdy w ogóle z niej nie korzysta. Wystarczy, że ma on taką możliwość, którą daje mu prawa własności. Natomiast pojęcie władania zawęża się w przypadku podmiotów, które nie są właścicielami rzeczy ani nie mają do niej praw zakładających władanie (np. użytkownicy). Ich wykonywanie władztwa musi być efektywne, gdyż w takim przypadku władanie nie jest „zakotwiczone” w prawie mającym za przedmiot.

W orzecznictwie podkreślono, że „małżonek może ponosić odpowiedzialność karna z art. $284 \S 1$ k.k., ale tylko w takim przypadku, gdy dopuszcza się rozporządzania mieniem należącym do majątku wspólnego w taki sposób, że czyni to z zamiarem powiększenia swego majątku kosztem majątku dru-

${ }_{17}$ M. Gałązka, w: A. Grześkowiak, K. Wiak (red.), op. cit., s. 1175.

${ }^{18}$ Postanowienie SN z 3 kwietnia 2002 r., V KKN 275/00, Lex nr 53073. 
giego małżonka, np. sprzedaje określoną rzecz ruchomą - postępuje w taki sposób, by ta rzecz nie mogła być w przyszłości przedmiotem podziału majątku wspólnego”19. Wskazuje się, że: „do popełnienia przestępstwa przywłaszczenia niezbędne jest rozporządzenie cudzą rzeczą tak jak właściciel, celem powiększenia własnego lub cudzego majątku kosztem pokrzywdzonego oraz istnienie po stronie sprawcy świadomości, że rozporządza konkretną rzeczą pomimo braku do tego tytułu prawnego. Jeżeli sprawca uważa, że ma prawo dysponować będącym w jego posiadaniu mieniem, to brak jest umyślności w jego działaniu, a więc czyn jego może być co najwyżej oceniony w aspekcie prawa cywilnego, bo nie wypełnia swoim zachowaniem znamion strony podmiotowej przestępstwa z art. $284 \S 1 \mathrm{k} . \mathrm{k}$. Przechodząc na grunt przedmiotowej sprawy należy zauważyć, że wszystkie przedmioty, których przywłaszczenie zostało przypisane oskarżonej stanowiły mienie »dorobkowe» małżonków P., których małżeństwo zostało rozwiązane przez rozwód [współwłasność łączna stała się współwłasnością w częściach ułamkowych - T.T.], wyrokiem Sądu Okręgowego w P. z 30 listopada 2010 r., przy czym do podziału majątku wspólnego nie doszło. Tak więc, przedmioty ruchome, które w zarzucie zostały wymienione, stanowiły jej małżeńską wspólność ustawową. [...] O przywłaszczeniu, w sytuacji gdy pokrzywdzonym miałby być jeden z małżonków, można by mówić wtedy, gdyby jedno z nich rozporządziło mieniem większej wartości niż przypadłoby jej w następstwie podziału majątku wspólnego"20.

Należy odróżniać przypadki przywłaszczenia rzeczy od uniemożliwiania współwłaścicielowi aktualnego władania rzeczą (korzystania z niej). Współwłaścicielowi majątku wolno wyłącznie władać rzeczą wbrew woli współwłaściciela w krótszym okresie bez uznania tego za działanie w celu przywłaszczenia. Do stwierdzenia przywłaszczenia konieczny jest upływ dłuższego okresu lub dokonanie czynności potwierdzającej zamiar przywłaszczenia (np. zbycie rzeczy). Czyn taki należy jednak kwalifikować z art. $284 \S 1$ k.k. Wydaje się, że jeżeli współwłaściciel włada wyłącznie rzeczą wbrew woli innych współwłaścicieli w celu przywłaszczenia rzeczy, ale okres ten jest jeszcze za krótki, aby uznać, że ono nastapiło, to czyn taki można kwalifikować jako usiłowanie przywłaszczenia (art. $13 \S 1 \mathrm{w}$ zw. z art. $284 \S 1$ k.k.).

Spadek jest wyodrębnioną masą majątkowa, która podlega takiej samej ochronie prawnokarnej jak mienie należące do innych podmiotów. Współwłasność rzeczy wchodzących w skład spadku stanowi współwłasność w częściach ułamkowych. W przypadku wspólności majątku spadkowego można wyróżnić dwie sytuacje prawne: wspólność całej masy spadkowej oraz współwłasność poszczególnych rzeczy wchodzących w skład spadku. Współwłasnością rozumiana ściśle jest tylko ta ostatnia. Wszystkie prawa majątkowe inne niż własność, wchodzące w skład spadku i istniejące w chwili jego otwarcia, należy

${ }^{19}$ Wyrok SN z 14 listopada 1972 r., V KRN 421/72, „Orzecznictwo Sądu Najwyższego Izba Karna i Wojskowa” 1973, nr 5, poz. 61; wyrok SA w Poznaniu z 13 grudnia 2012 r., II AKa 258/12, Lex nr 1307474.

20 Ibidem. 
zaklasyfikować jako wspólność, do której stosuje się odpowiednio przepisy o współwłasności w częściach ułamkowych.

Zdaniem Anny Piaczyńskiej: „zagrożenie dla aktywów masy spadkowej powodują zwłaszcza czynności rozporządzające, które prowadzą do definitywnego uszczuplenia składu spadku, takie jak zbycie poszczególnych przedmiotów spadkowych czy też zdarzenia faktyczne, jak zniszczenie rzeczy. Mogą one prowadzić do powstania roszczeń z bezpodstawnego wzbogacenia lub roszczeń odszkodowawczych, które zresztą mogą być dochodzone także w procesie karnym. Należy podkreślić, iż samowolne zbycie całej rzeczy spadkowej, jako czynność przekraczajacca zakres zwykłego zarządu, zawsze pozostanie działaniem bezprawnym. Żaden przepis nie uprawnia współspadkobiercy do takich czynności, dopiero zgoda wszystkich współspadkobierców, zgodnie z art. 199 k.c., prowadziłaby do wyłączenia bezprawności”"21. Powołana autorka trafnie dopuszcza przywłaszczenie rzeczy wchodzacej w skład spadku, wykluczając możliwość jej kradzieży w związku ze współposiadaniem składników spadku. Podkreśla ona, że „ustawodawca na gruncie prawa prywatnego traktuje spadek, współwłasność w częściach ułamkowych oraz wspólność majątkową małżeńską na zasadzie wzajemnych odesłań, a zatem błędem logicznym byłoby traktowanie wspomnianych wspólności odmiennie w prawie karnym"22. Krytycznie należy odnieść się do poglądu Zygmunt Kukuły, zdaniem którego pociągnięcie spadkobiercy do odpowiedzialności karnej jest możliwe dopiero po wydaniu postanowienia o stwierdzeniu nabycia spadku oznaczającego udziały poszczególnych współspadkobierców ${ }^{23}$. Postanowienie o stwierdzeniu nabycia spadku ma jedynie charakter deklaratoryjny. Spadkobierca nabywa własność spadku ex tunc, czyli ex lege z chwila śmierci spadkodawcy.

Przedmiotem wykonawczym kradzieży mogą być rzeczy używane wspólnie przez osoby pozostające w konkubinacie, pod warunkiem że nie stanowia współwłasności. Rzeczy nabyte w trakcie trwania konkubinatu przez osoby, które go tworza, nie stanowią współwłasności ${ }^{24}$. Należy jednak podkreślić, że w przypadku zaboru rzeczy przez osobę zamieszkującą z pokrzywdzonym, która zaprzecza chęci przywłaszczenia, należy ponad wszelką wątpliwość ustalić, że zmierzała ona do definitywnego pozbawienia właściciela władztwa. W przeciwnym razie wypełnia ona znamiona art. $127 \S 1$ k.w. lub 289 k.k. Moim zdaniem w takim przypadku sąd nie może domniemywać działania w celu przywłaszczenia, tak jak np. w przypadku kradzieży sklepowej, kieszonkowej, z włamaniem czy rozboju. W opisie czynu powinny znaleźć się wtedy szczegółowe ustalenia faktyczne, które łącznie tworzyć będą spójny obraz strony przedmiotowej, na podstawie której logicznie i ponad wszelką wątpliwość będzie można ustalić cel przywłaszczenia.

Inny jest status rzeczy wchodzaccych w skład majątku spółki cywilnej i osobowej spółki prawa handlowego niż spółki z o.o. W przypadku spółki cywilnej

${ }^{21}$ A. Piaczyńska, Przywłaszczenie składnika spadku przez wspótspadkobiercę, „Prokuratura i Prawo" 2011, nr 3, s. 91.

${ }^{22}$ Ibidem.

${ }^{23}$ Z. Kukuła, Prawnokarna ochrona spadku, „Przegląd Sądowy” 2009, nr 2, s. 116-117.

${ }^{24}$ M. Dąbrowska-Kardas, P. Kardas, w: A. Zoll (red.), op. cit., s. 47. 
występuje współwłasność łączna, tak samo jak w małżeńskiej wspólnocie majątkowej. Zasadniczo możliwa jest wyłącznie realizacja znamion przestępstwa przywłaszczenia (art. $284 \S 1$ k.k.). Analogicznie należy oceniać osobowe spółki prawa handlowego, gdyż „zabór” rzeczy przez wspólnika jest możliwy jedynie w stosunku do majątku spółki kapitałowej (osoby prawnej).

Małgorzata Dąbrowska-Kardas i Piotr Kardas trafnie podkreślaja, że: „zabór i tym samym kradzież jest możliwa w stosunku do rzeczy stanowiącej własność odrębnego podmiotu, który z kolei, jak na przykład spółka prawa handlowego, z ekonomicznego punktu widzenia jako całość (odrębny przedmiot) stanowi współwłasność wspólników, na przykład kilku osób fizycznych. Przykładowo, wspólnicy spółki z ograniczoną odpowiedzialnością są właścicielami majątku spółki tylko w znaczeniu ekonomicznym. Własność tego majątku w znaczeniu prawnym przysługuje natomiast spółce jako odrębnemu podmiotowi prawnemu. Dlatego też majątek spółki z o.o. nie jest własnością jej wspólników. Wychodząc z tych założeń, SN stwierdził, że rzeczy stanowiące własność spółki z ograniczoną odpowiedzialnością stanowią dla jej wspólników rzeczy cudze, dlatego też mogą stanowić przedmiot zaboru dokonanego przez wspólnika lub wspólników” ${ }^{25}$. Ich zdaniem: „zabór możliwy jest w stosunku do mienia stanowiącego własność spółdzielni. Trafnie wskazuje bowiem SN, że art. 3 ustawy - prawo spółdzielcze w brzmieniu nadanym po nowelizacji z 1994 r. nie pozbawia spółdzielni własności jej majątku i nie czyni spółdzielców współwłaścicielami w rozumieniu prawa cywilnego, a jedynie zalicza własność należąca do spółdzielni jako osoby prawnej do kategorii własności prywatnej, a nie jak w poprzednio obowiązującym stanie prawnym - spółdzielczej. Własność taka, w rozumieniu przepisów prawa karnego, pozostaje jednak własnością cudza, a jej przedmiot jest cudzym mieniem, także dla członka spółdzielni”" ${ }^{26}$.

W orzecznictwie podkreślono, że: „regulacja organizacyjnoprawna spółki nie upoważnia wspólników (czy jednego wspólnika), z tytułu posiadanych udziałów w spółce, do rozporządzania jej mieniem. Zarówno kapitał zakładowy, jak i jej majątek stanowią własność spółki jako samodzielnego podmiotu gospodarczego. Charakter majątku nie ulega nawet zmianie wówczas, gdy wspólnikiem w spółce z o.o. jest jedna osoba. Dysponować nim moga - w granicach określonych przepisami - organy spółki, a nie poszczególni wspólnicy. Tak więc mienie spółki z o.o., jest dla udziałowców spółki mieniem cudzym”"27. Trafnie wskazuje się w orzecznictwie i literaturze, że jeżeli nie powstał odrębny i legalny tytuł prawny do korzystania przez wspólnika z określonego składnika majątku (np. najem, dzierżawa, powierzenie mienia pracownikowi), to jest możliwy jego zabór przez wspólnika. Czyn ten należy wtedy kwalifikować

${ }^{25}$ Ibidem, s. 47. Tak też L. Wilk, w: M. Królikowski, R. Zawłocki (red.), op. cit., s. 533.

${ }^{26}$ M. Dąbrowska-Kardas, P. Kardas, w: A. Zoll (red.), op. cit., s. 47 i 47-48. Tak też wyrok SN z 9 lipca 2003 r., III KK 334/02, Lex nr 80298; L. Wilk, w: M. Królikowski, R. Zawłocki (red.), op. cit., s. 533.

27 Wyrok SA w Białymstoku z 20 listopada 2012 r., II AKa 138/12, Lex nr 1278079. Tak też uchwała SN z 20 maja 1993 r., I KZP 10/93, „Orzecznictwo Sądu Najwyższego Izba Karna i Wojskowa” 1993, nr 7-8, poz. 44. 
jako kradzież, a nie jako przywłaszczenie ${ }^{28}$. Natomiast jeżeli istniał taki tytuł prawny i związane z nim było prawo do swobodnego korzystania ze składnika majątku spółki, to osoba prawo takie posiadająca nie dokonuje zaboru i może odpowiadać za przestępstwo przywłaszczenia. Należy jednak pamiętać o przepisie art. 296 k.k., który wydaje się stanowić lex specialis wobec przepisów typizujących kradzież oraz przywłaszczenie.

Specyficzna sytuacja występuje w przypadku jednoosobowej spółki z o.o. Wydaje się, że formalnie majątek takiej spółki jest rzeczą cudzą dla jej właściciela. Jedyny udziałowiec może być także zatrudniony jako organ tej spółki. Dlatego też jeżeli przeniesie on rzecz z majątku spółki do majątku osobistego w celu przywłaszczenia, to choć przedmiotem tej czynności jest rzecz cudza, zdekompletowana może być strona podmiotowa kradzieży. Działając bowiem jako organ spółki, może on wyrazić na to zgodę. O tym, czy wyrażenie takiej zgody było skuteczne, rozstrzygają przepisy k.s.h. Możliwa jest więc kradzież majątku spółki z o.o. przez jej jedynego udziałowca, jeżeli naruszył on przepisy prawa handlowego. Redukcja majątku spółki może wiązać się z pokrzywdzeniem wierzycieli i dlatego czyn taki może być społecznie szkodliwy. Dlatego też rację ma SN, że: „regulacja organizacyjno-prawna spółki z ograniczoną odpowiedzialnością nie upoważnia wspólników (czy jednego wspólnika), z tytułu posiadanych udziałów w spółce, do rozporządzenia mieniem spółki. Zarówno kapitał zakładowy, jak i majątek spółki stanowią bowiem własność spółki jako samodzielnego podmiotu gospodarczego. Charakter majątku nie ulega zmianie także wówczas, gdy wspólnikiem w spółce z o.o. jest jedna osoba. Dysponować nim moga - w granicach określonych przepisami - organy spółki, a nie poszczególni wspólnicy”29.

Kolejną kwestią wymagająca rozstrzygnięcia, w szczególności w związku z kontrawencjonalizacją przestępstw kradzieży i przywłaszczenia, jest wartość składnika majątku stanowiącego współwłasność łączna. Trafnie podkreśla R.A. Stefański, że ma ona charakter bezudziałowy i dopiero z chwilą ustania wspólności ustawowej ulega ona przekształceniu we współwłasność $\mathrm{w}$ częściach ułamkowych ${ }^{30}$. Generalnie będą to udziały równe, lecz należy zwrócić uwagę, że zgodnie z art. $43 \S 2$ k.r.o., z ważnych powodów każdy z malżonków może żądać, ażeby ustalenie udziałów w majątku wspólnym nastapiło z uwzględnieniem stopnia, w którym każdy z nich przyczynił się do powstania tego majątku. Słusznie wskazuje powołany autor, że nie ma podstaw, aby od wartości rzeczy odjąć część przypadającą w przyszłości sprawcy ${ }^{31}$. Należy więc przyjmować pełna wartość przedmiotu wykonawczego. Fakt, że sprawca był współwłaścicielem przywłaszczonej rzeczy, nie wpłynie więc na kwalifikację.

${ }^{28}$ Wyrok SA we Wrocławiu z 23 października 2006 r., II Aka 224/06, „Prokuratura i Prawo dodatek Orzecznictwo” 2008, nr 4, poz. 20; T. Oczkowski, A. Marek, w: R. Zawłocki (red.), op. cit., s. 75 .

${ }^{29}$ Uchwała SN z 20 maja 1993 r., I KZP 10/93, „Orzecznictwo Sądu Najwyższego Izba Karna i Wojskowa" 1993, nr 7-8, poz. 44.

30 R.A. Stefański, op. cit., s. 122.

31 Ibidem. 
Wydaje się jednak, że powinien wpłynąć na wymiar kary, która z tego powodu powinna być niższa.

Moim zdaniem należy przyjmować jednak „niepełną” wartość przedmiotu wykonawczego w przypadku kradzieży rzeczy stanowiącej współwłasność w częściach ułamkowych. Wartość przywłaszczonego mienia stanowić będzie wartość udziałów pokrzywdzonych.

Ustalenie możliwości przywłaszczenia składnika majątku stanowiącego współwłasność wymaga prawidłowego ustalenia strony podmiotowej. Zdaniem J.F. Marca sprawca takiego czynu ma „pewne prawa” do zabranego mienia i z tego tytułu jego świadomość może budzić wątpliwości. Podkreśla on, że: „nie można pomijać faktu, iż wśród większości obywateli panuje przekonanie, że przedmioty nabyte w okresie trwania związku małżeńskiego są własnościa tego, za czyj "zarobek" (wynagrodzenie za pracę) zostały one nabyte. [...] Stąd wśród małżonków, zwłaszcza rozchodzących się, istnieje mniemanie, że rzeczami może dysponować wyłącznie ten, kto je nabył. Dlatego też mąż często sprzedaje, bez względu na to, w jakim celu, przedmioty urządzenia domowego, przeznaczając uzyskane pieniądze według swego zapatrywania. Wskazane działanie małżonka bywa dokonane w przekonaniu, że dysponuje rzeczą własną, której jest wyłącznym właścicielem. Taki stan rzeczy wykluczałby istnienie winy z powodu błędu, co do okoliczności należącej do istoty czynu" ${ }^{32}$.

Trafnie podkreśla się, że należy szczególnie wnikliwie analizować stronę podmiotowa, jeżeli przedmiotem wykonawczym jest rzecz stanowiąca współwłasność małżeńską. Możliwość występowania błędu co do faktu oraz co do prawa jest $\mathrm{w}$ tych przypadkach wyjątkowo częsta. Przeświadczenie o własności rzeczy, która w rzeczywistości jest cudza, wyłacza zamiar ${ }^{33}$. Natomiast R.A. Stefański wskazuje, że błąd co do tego, że zabrane mienie stanowi cudzą własność, należy oceniać na płaszczyźnie błędu co do faktu. Błąd co do prawa rozporządzania rzeczą jest błędem co do okoliczności należącej do istoty czynu. Nieświadomość bezprawności czynu obejmuje jedynie błąd co do prawa, czyli nieznajomość przepisów, a nie nieświadomość okoliczności należących do istoty czynu ${ }^{34}$. Zwrócił na to uwagę także SN w wyroku z 30 stycznia $1946 \mathrm{r}$. Zdaniem SN: „przestępstwo kradzieży jako czyn umyślny wymaga ustalenia świadomości sprawcy, że nie posiada on żadnych praw do zabranego mienia; kto zatem zabiera mienie w przekonaniu chociażby błędnym, że stanowi ono jego własność, nie popełnia kradzieży wobec braku zamiaru przywłaszczenia” ${ }^{35}$. „Kwalifikowana postać przywłaszczenia, tj. sprzeniewierzenia, należy do przestępstw kierunkowych. Zachowanie sprawcy musi być ukierunkowane na określony cel, którym jest włączenie powierzonej rzeczy do majątku spraw-

32 J.F. Marzec, Z problematyki zaboru przez jednego z matżonków mienia objętego współwłasnościq ustawowa, „Państwo i Prawo” 1959, z. 11, s. 854. Stwierdzenie powołanego autora o braku winy jest już obecnie powszechnie odrzucane, gdyż błąd co do znamion wyłącza już istotę czynu i ostatni element struktury przestępstwa nie jest badany. Wynika to z sekwencyjnego charakteru szczebli struktury przestępstwa.

${ }^{33}$ L. Kubicki, $W$ sprawie..., s. 856-857.

${ }^{34}$ R.A. Stefański, op. cit., s. 122.

35 Wyrok SN z 30 stycznia 1946 r., K 379/45, Lexis nr 410852. 
cy lub postępowanie z nią jak z własną w inny sposób. Istotnym elementem strony podmiotowej sprzeniewierzenia nie jest sam fakt odmowy wydania rzeczy powierzonej, lecz powody jej niezwrócenia, a więc wola włączenia rzeczy do swojego majątku lub wola postępowania z nią jak z własną”36. „O zamiarze w przypadku tego typu przestępstwa nie przesądza sam fakt nieuprawnionego postępowania z rzecza, a więc wykorzystywanie jej lub postępowanie z nia w sposób inny niż uzgodniony z właścicielem. Niezbędne jest wykazanie, że sprawca, postępując z rzeczą jak z własna (animus rem sibi habendi), w sposób sprzeczny z uzgodnieniami poczynionymi z właścicielem, działał w celu włączenia rzeczy do swojego majątku i definitywnego pozbawienia osoby uprawnionej jej własności”37. Należy podkreślić, że realizacja strony podmiotowej kradzieży mienia stanowiącego majątek wspólny wymaga wykazania, że sprawca miał zamiar bezpośredni powiększenia swojego majątku kosztem współwłaściciela.

W doktrynie nie analizowano natomiast abstrakcyjnego stopnia bezprawia przestępstwa przywłaszczenia rzeczy ze współwłasności w stosunku do czynu, którego przedmiotem jest rzecz niebędąca współwłasnością sprawcy i pokrzywdzonego. Moim zdaniem w tym pierwszym przypadku jest on niższy, sprawca bowiem posiada prawo własności do przedmiotu wykonawczego.

dr Tomasz Tyburcy

tyburcy@vp.pl

\section{THEFT OR MISAPPROPRIATION OF A TANGIBLE ASSET AS THE MATRIMONIAL PROPERTY}

\section{Summary}

According to the dominant opinion in the case-law, the spouse who disposes of the assets included within the matrimonial property against the will of the other spouse commits either a theft or misappropriation, depending on which party (the perpetrator or the victim) controls the assets in question. There is, however, a minority view according to which it is not possible for a spouse to commit a crime of stealing assets included in the matrimonial property and any unlawful appropriation of such assets by a spouse must be qualified in accordance with Article 284 par. 1 of the Penal Code. Both positions have their basis in the understanding of the notion of 'possession' as a subject of protection under the legal provisions in which offences against property are defined. It is generally accepted that what matters is the factual ownership of a given object, but there is no agreement in the literature as to the uniform definition of this ownership.

${ }^{36}$ Wyrok SA w Białymstoku z 20 listopada 2012 r., II AKa 138/12, Lex nr 1278079. Tak też wyrok SN z 14 stycznia 2003 r., II KKN 273/01, Lex nr 75381.

${ }^{37}$ Wyrok SA w Białymstoku z 20 listopada 2012 r., II AKa 138/12, Lex nr 1278079. Tak też wyrok SN z 6 maja 2004 r., V KK 316/03, „Orzecznictwo Sądu Najwyższego Izba Karna i Wojskowa” 2004, nr 7-8, poz. 70. 
